\title{
EFEK HIPOGLIKEMIK EKSTRAK BIJI BUAH WALI (Brucea Javanica L. Merr) PADA TIKUS WISTAR YANG DIINDUKSI ALOKSAN
}

\section{EFEK HIPOGLIKEMIK EKSTRAK BIJI BUAH WALI (Brucea Javanica L. Merr) PADA TIKUS WISTAR YANG DIINDUKSI ALOKSAN}

\author{
Ida Bagus Putra Manuaba ${ }^{1)}$, Faturrahman'), Candra Dwipayana Hamdin ${ }^{3)}$ \\ ${ }^{1)}$ Program Studi Farmasi Universitas Mataram, Mataram, Indonesia \\ 2)Program Studi Biologi, Universitas Mataram, Mataram, Indonesi \\ ${ }^{3)}$ Program Studi Farmasi, Universitas Mataram, Mataram, Indonesia \\ Email: Manuaba96@gmail.com
}

Diterima: 21 Januari 2020. Disetujui: 23 Januari 2020. Dipublikasikan: 31 Januari 2020

\begin{abstract}
Abstrak: Buah wali (Brucea javanica L. Merr) telah lama digunakan sebagai obat penyakit diabetes oleh masyarakat di daerah Sesaot. Tujuan penelitian ini adalah mengetahui efek hipoglikemik ekstrak biji buah wali terhadap kadar gula darah puasa (GDP) tikus wistar yang mengalami diabetes. Penelitian ini menggunakan metode experimental dengan rancangan acak lengkap (RAL). Terdapat delapan kelompok perlakuan yaitu kelompok kontrol positif $(\mathrm{K}+)$ dengan terapi glibenklamid $0.5 \mathrm{mg} / \mathrm{kgBB}$, kelompok kontrol negatif (K-) yaitu hewan diabetes dengan pemberian cmc na $0.5 \%$, kelompok $\mathrm{N}$ adalah hewan tidak diabetes dan kelompok pemberian variasi dosis ekstrak biji buah wali (D1, D2, D3, D4, dan D5). Pembuatan hewan model diabetes dilakukan dengan cara induksi aloksan $(125 \mathrm{mg} / \mathrm{kgBB})$ secara intravena pada setiap kelompok kecuali pada kelompok N. Analisis data dilakukan dengan uji Anova dan LSD. Hasil penelitian ini menunjukkan persentase penurunan rata-rata gula darah selama 15 hari pengamatan sebesar 4\% (D1), $10 \%$ (D2), 22\% (D3), 6\% (D4), 6\% (D5), 14\% (K+), 4\% (K-), dan 2\% pada kelompok N. Hasil uji Anova menunjukan bahwa $\mathrm{p}<0,05$ yang berarti ada pengaruh pemberian ekstrak biji buah wali terhadap penurunan kadar gula darah tikus. Uji LSD menunjukkan pengaruh signifikan terjadi pada kelompok K+ dan kelompok variasi dosis ekstrak terhadap kelompok K- dengan nilai LSD p <0.05. Berdasarkan hasil penelitian ini, esktrak biji buah wali dapat menurunkan kadar gula darah puasa pada hewan uji diabetes dengan penurunan terbesar (22\%) pada kelompok D3 dengan dosis $25 \mathrm{mg} / \mathrm{kgBB}$.
\end{abstract}

Kata Kunci: Ekstrak biji buah wali (Brucea javanica L. Merr), Diabetes, Hipoglikemik

\begin{abstract}
Buah wali (Brucea javanica L. Merr) telah lama digunakan sebagai obat penyakit diabetes oleh masyarakat di daerah Sesaot. Tujuan penelitian ini adalah mengetahui efek hipoglikemik ekstrak biji buah wali terhadap kadar gula darah puasa (GDP) tikus wistar yang mengalami diabetes. Penelitian ini menggunakan metode experimental dengan rancangan acak lengkap (RAL). Terdapat delapan kelompok perlakuan yaitu kelompok kontrol positif $(\mathrm{K}+)$ dengan terapi glibenklamid $0.5 \mathrm{mg} / \mathrm{kgBB}$, kelompok kontrol negatif (K-) yaitu hewan diabetes dengan pemberian $\mathrm{cmc}$ na $0.5 \%$, kelompok $\mathrm{N}$ adalah hewan tidak diabetes dan kelompok pemberian variasi dosis ekstrak biji buah wali (D1, D2, D3, D4, dan D5). Pembuatan hewan model diabetes dilakukan dengan cara induksi aloksan $(125 \mathrm{mg} / \mathrm{kgBB})$ secara intravena pada setiap kelompok kecuali pada kelompok N. Analisis data dilakukan dengan uji Anova dan LSD. Hasil penelitian ini menunjukkan persentase penurunan rata-rata gula darah selama 15 hari pengamatan sebesar 4\% (D1), 10\% (D2), 22\% (D3), 6\% (D4), 6\% (D5), 14\% (K+), 4\% (K-), dan 2\% pada kelompok N. Hasil uji Anova menunjukan bahwa $\mathrm{p}<0,05$ yang berarti ada pengaruh pemberian ekstrak biji buah wali terhadap penurunan kadar gula darah tikus. Uji LSD menunjukkan pengaruh signifikan terjadi pada kelompok K+ dan kelompok variasi dosis ekstrak terhadap kelompok K- dengan nilai LSD p <0.05. Berdasarkan hasil penelitian ini, esktrak biji buah wali dapat menurunkan kadar gula darah puasa pada hewan uji diabetes dengan penurunan terbesar (22\%) pada kelompok D3 dengan dosis $25 \mathrm{mg} / \mathrm{kgBB}$.
\end{abstract}

Keywords: Ekstrak biji buah wali (Brucea javanica L. Merr), Diabetes, Hipoglikemik

\section{PENDAHULUAN}

Diabetes mellitus adalah suatu jenis penyakit yang disebabkan karena tingginya kadar gula darah dalam tubuh. Kadar gula darah yang tinggi dapat dipengaruh oleh beberapa faktor seperti menurunnya kadar hormon insulin, sensitivitas insulin yang menurun, ataupun autoimun [1][2].

Indonesia menempati urutan ke-9 sebagai negara dengan jumlah penderita diabetes terbanyak di dunia dan sekitar 7 juta jiwa menderita diabetes. Tahun 2030, Indonesia diperkirakan menjadi negara dengan penderita diabetes terbanyak urutan ke-6 dan perkiraan populasi penderita diabetes sebanyak 12 juta jiwa [3]. Kasus penyakit diabetes yang tinggi menjadi pemicu dalam pengembangan terapi diabetes baik dengan pengobatan konvensional maupun dengan pengobatan tradisional. 
Brucea javanica L. Merr adalah salah satu tanaman yang bijinya dipercaya memiliki khasiat obat. Tanaman ini lebih dikenal dengan sebutan buah makasar/buah wali di daerah Sesaot Lombok Barat. Buah wali tidak dianjurkan untuk dikonsumsi secara berlebihan, karena beberapa penelitian melaporkan bahwa buah wali memiliki potensi yang dapat menimbulkan gejala keracunan [4].

Ekstraksi adalah proses penarikan kandungan kimia yang dapat larut dari suatu serbuk simplisia, sehingga terpisah dari bahan yang tidak dapat larut. Metode yang banyak digunakan untuk ekstraksi bahan alam salah satunya adalah maserasi. Maserasi adalah proses ekstraksi simplisia menggunakan pelarut dengan beberapa kali pengadukan pada suhu ruangan. Ekstraksi secara menyeluruh juga dapat menghabiskan sejumlah besar ph pelarut yang dapat berpotensi hilangnya metabolit. Beberapa senyawa juga tidak terekstraksi secara efisien jika kurang terlarut pada suhu kamar $\left(27^{\circ} \mathrm{C}\right)$

Aloksan dapat dimanfaatkan sebagai agen penginduksi diabetes eksperimental pada hewan. Mekanisme aksi aloksan di sel B pankreas telah banyak diteliti dan dapat untuk dipahami. Aloksan menghasilkan suatu produk reduksi yaitu asam dialurat. Asam dialurat dapat membentuk siklus redoks dengan pembentukan radikal superoksida. Radikal ini mengalami dismutasi menjadi hidrogen peroksida. Radikal hidroksil yang sangat reaktif dibentuk dari reaksi Fenton. Sehingga akan terjadi penghancuran sel B pankreas secara cepat karena adanya peningkatan konsentrasi kalsium sitosolik secara simultan [5].

Hewan percobaan yang umum digunakan dalam penelitian ilmiah adalah tikus. Tikus (Rattus norvegicus) telah diketahui sifat-sifatnya secara sempurna, mudah dipelihara, dan merupakan hewan yang relatif sehat dan cocok untuk berbagai penelitian [6].

Tujuan penelitian ini adalah mengetahui efek hipoglikemik ekstrak biji buah wali terhadap kadar gula darah puasa (GDP) tikus wistar yang mengalami diabetes. Pengujian efek biji buah wali dapat di uji coba pada hewan model untuk mengetahui efek penurunan gula darah dari dosis yang biasa digunakan di masyarakat.

\section{METODE PENELITIAN}

Jenis penelitian yang dilakukan kali ini adalah jenis penelitan eksperimental karena memberikan perlakuan kepada populasi dan sampel serta adanya kelompok kontrol dalam penelitian dengan desain penelitan menggunakan rancangan acak lengkap (RAL) [7]. Penelitian akan dilaksanakan pada bulan April 2018. Penelitian dan pemeliharaan hewan uji, akan dilakukan di laboratorium Farmakologi Program Studi Farmasi Universitas Mataram.

1. Alat dan Bahan Penelitian
Peralatan yang digunakan dalam penelitian ini menggunakan peralatan yang tersedia di laboratorium Farmakologi Program Studi Farmasi Universitas Mataram. Pengukuran gula darah puasa hewan uji menggunakan alat Accucheck perfoma. Bahan yang digunakan dalam penelitian ini seperti buah wali diambil dari salah satu kawasan hutan di daerah Sesaot, Lombok Barat. Hewan uji yang digunakan pada penelitian ini adalah tikus putih galur wistar.

\section{Ekstraksi}

Pembuatan Ekstrak dalam penelitian ini dilakukan dengan cara maserasi dengan bahan utama yaitu biji buah wali (Brucea javanica L. Merr.). Biji buah dikering anginkan selama 3 hari, kemudian dipisahkan terlebih dahulu dengan cangkang biji yang bersifat keras, kemudian biji buah digerus dalam mortir sampai halus. Setelah biji digerus, biji buah di rendam dengan pelarut etanol $96 \%$ lalu didiamkan selama 3 hari. Setelah hari ketiga, larutan kemudian disaring untuk dipisahkan ampas dan pelarutnya, yang selanjutnya pelarut yang telah bercampur dengan zat zat yang terdapat dalam buah akan di evaporasi. Memisahkan pelarut dan zat yang terbawa dalam pelarutnya menggunakan vacum rotary evaporator.

3. Hewan Uji

Sebanyak 24 hewan uji dibagi menjadi delapan kelompok. Delapan kelompok perlakuan yaitu kelompok kontrol positif $(\mathrm{K}+)$ dengan terapi glibenklamid $0.5 \mathrm{mg} / \mathrm{kgBB}$, kelompok kontrol negatif (K-) yaitu hewan diabetes dengan pemberian cmc na $0.5 \%$, kelompok $\mathrm{N}$ adalah hewan tidak diabetes dan kelompok pemberian variasi dosis ekstrak biji buah wali (D1, D2, D3, D4, dan D5). Masing masing kelompok terdapat tiga ekor hewan uji. Setelah pembagian kelompok, dilakukan spenyesuaian lingkungan untuk memberikan waktu beradaptasi pada hewan sekitar satu minggu. Pemberian pakan diberikan dengan takaran 50 gr pada masing masing kelompok dan dilakukan penimbangan berat hewan uji secara berkala setiap lima hari untuk menyeragamkan bobot hewan pada rentang 200 gram. Pembuatan hewan uji diabetes, dilakukan dengan cara induksi aloksan dengan dosis $125 \mathrm{mg} / \mathrm{kgBB}$ secara intravena.

4. Uji Efek Hipoglikemik Ekstrak Biji Buah Wali

Setelah tahap penyesuaian lingkungan selesai dan didapatkan berat rata rata hewan uji yang diinginkan, kemudian diberikan aloksan secara intravena untuk menimbulkan kondisi diabetes pada hewan uji. Sebelum induksi aloksan dilakukan, setiap kelompok di puasakan selama 8 jam yang kemudian dilakukan pengambilan data gula darah puasa awal dan dilakukan pengamatan gula darah tiga hari setelah induksi aloksan sebagai data pembanding gula darah puasa sebelum induksi aloksan dan sesudah induksi aloksan. Setelah hewan uji mengalami 
kenaikan kadar gula darah atau menjadi hiperglikemik, selanjutnya dilakukan pemberian ekstrak hari pertama. Pengambilan data gula darah selanjutnya dilakukan dengan cara hewan uji dipuasakan selama 8 jam sebelum dilakukan pengamatan kadar gula darah dan sebanyak tiga kali dengan jarak lima hari sekali pada hewan uji di setiap kelompok perlakuan. Setelah dilakukan pengujian pada hewan uji, selanjutnya data yang diperoleh akan diolah. Hasil percobaan diolah secara statistik dengan uji analisis varians (ANOVA) satu arah kemudian uji LSD untuk melihat adanya perbedaan kadar glukosa darah hewan uji antar kelompok yang berarti.

\section{HASIL DAN PEMBAHASAN Hasil Ekstraksi}

Proses Ekstraksi pada penelitian ini dilakukan dengan teknik maserasi. Maserasi dipilih karena maserasi merupakan cara ekstraksi yang paling mudah dengan rendemen ekstraksi tinggi [8]. Biji buah wali yang digerus halus sebanyak 340 gr dilarutkan dengan pelarut etanol 96\%. Pelarut etanol digunakan karena merupakan pelarut universal yang memiliki ekstraktibilitas yang baik pada hampir semua metabolit skunder (Saifudin, 2014). Hasil dari 340 gr biji buah yang dimaserasi kemudian evaporasi untuk memisahkan pelarut dan zat terlarutnya [9]. Hasil dari evaporasi didapatkan ekstrak kental sebanyak 24.4 gr, hasil tersebut kemudian dilanjutkan sebagai data untuk menghitung persen rendemen. Persen rendemen dapat dilakukan dengan perhitungan sebagai berikut:

Persen rendemen $=\frac{\text { Bobot elotrak }}{\text { Bobot Simplisia }} \times 100 \%$

$$
\begin{aligned}
& =\frac{24.4(\mathrm{gr})}{340(\mathrm{gr})} \times 100 \% \\
& =7.17 \%
\end{aligned}
$$

\section{Berat Badan Hewan Uji}

Rata-rata hewan uji selama 15 hari pengamatan berkisar mulai dari $172 \mathrm{gr}-224 \mathrm{gr}$. Kelompok perlakuan yang diberikan variasi dosis ekstrak buah wali menunjukkan berat badan yang cendrung stabil selama pengamatan. Berat badan yang cendrung stabil juga ditunjukkan oleh kelompok $\mathrm{K}+$ dan kelompok N. Selama 15 hari pengamatan, berat badan yang tidak stabil dan cendrung menurun ditunujukkan oleh kelompok kontrol negatif.

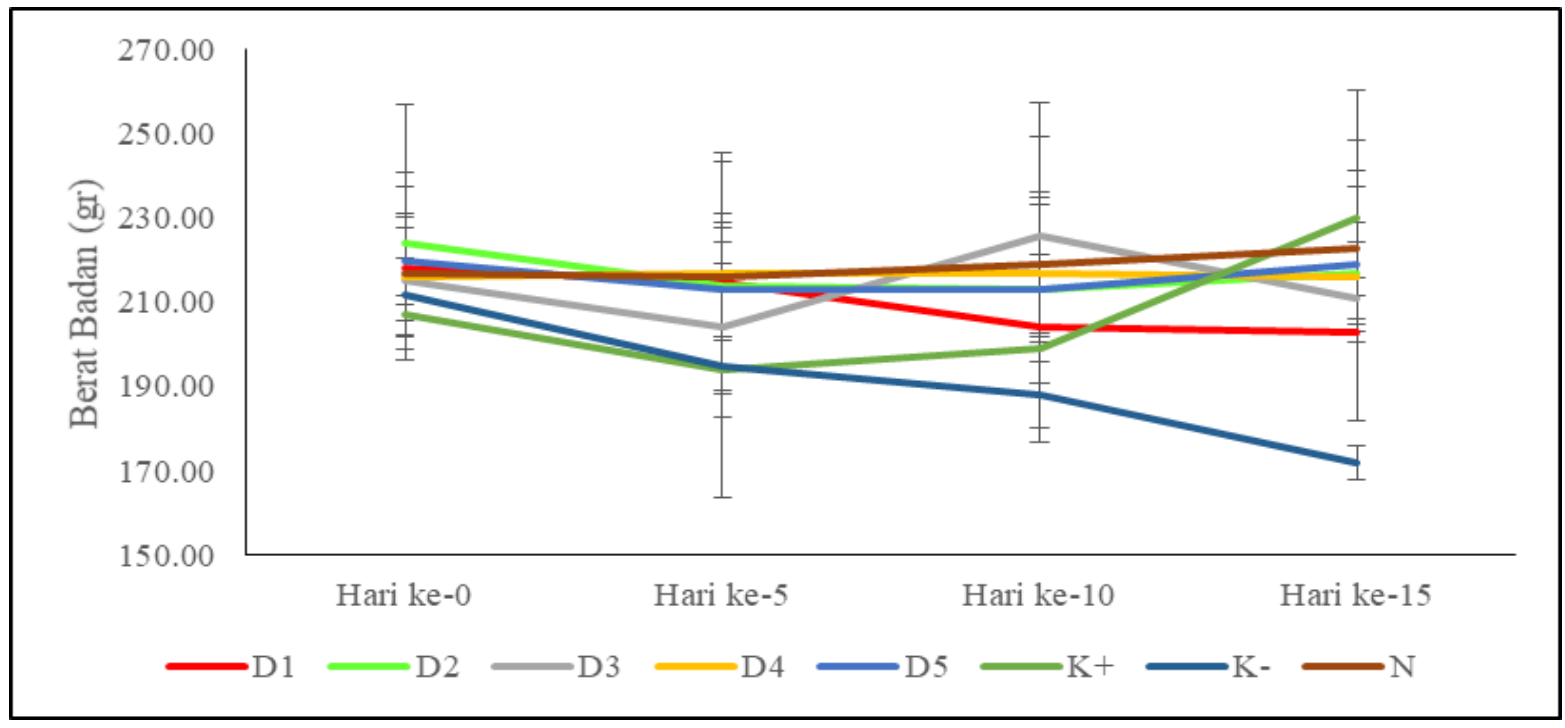

Gambar 1. Grafik Rata rata Berat Badan Hewan Uji Selama 15 Hari Pengamatan. D1 (Dosis $12.5 \mathrm{mg} / \mathrm{kgBB}$ ) ; D2 (Dosis $18.75 \mathrm{mg} / \mathrm{kgBB}$ ) ; D3 (Dosis $25 \mathrm{mg} / \mathrm{kgBB}$ ) ; D4 (Dosis $31.25 \mathrm{mg} / \mathrm{kgBB}$ ) ; D5 (Dosis 37.5 $\mathrm{mg} / \mathrm{kgBB}$ ) ; K+ (Kelompok Kontrol Positif) ; K- (Kelompok Kontrol Negatif) ; N (Kelompok Kontrol Normal).

Data rata rata berat badan terlebih dahulu dilakukan uji normalitas dan uji homogenitas untuk mengetahu data telah terdistribusi normal dan homogen. Pengolahan data dilakukan dengan aplikasi SPSS 16. Hasil analisis data disajikan secara terlampir dan setelah dilakukan analisis data, dikatakan data terdistribusi normal dan homogen, dengan siginifikasi $\mathrm{p}>0,05$ [8].

Pada gambar 1, dapat diamati grafik berat badan yang mengalami penurunan selama pengamatan terjadi pada kelompok K-. Penurunan rata rata berat badan yang terjadi pada kelompok $\mathrm{K}$ - menunjukkan adanya perbedaan dengan kelompok yang diberikan terapi obat maupun kelompok yang tidak diinduksi aloksan. Gambar 1 menunjukkan efek aloksan dapat menyebabkan penurunan berat badan pada hewan uji apabila tidak diberikan terapi. Aloksan dapat merusak jaringan lain selain dapat merusak jaringan sel b pankreas [5], sehingga dibutuhkan efek antioksidan endogen untuk dapat memulihkan jaringan yang rusak. Apabila produksi antioksidan endogen tidak 
mencukupi untuk dapat meperbaiki kerusakan jaringan, maka akan menimbulkan gangguan terhadap metabolisme sel dan berefek pada menurunnya nafsu makan [10]. Nafsu makan yang berkurang akibat dari efek aloksan, menjadi salah satu faktor terjadinya penurunan berat badan hewan uji yang tanpa diberikan terapi.

Kelompok hewan uji yang diberikan terapi dengan variasi dosis ekstrak dan glibenklamid menunjukkan grafik rata rata berat badan yang berbeda dibandingkan dengan kontrol negatif. Hal ini dapat disebabkan karena ekstrak buah wali dan glibenklamid dapat mengakibatkan perbaikan jaringan akibat efek dari induksi aloksan [11]. Perbaikan jaringan akibat pemberian terapi obat maupun dengan variasi dosis ekstrak dapat memperbaiki metabolisme sel dan mencegah kondisi sakit yang dapat menurunkan nafsu makan pada hewan uji [10].

1. Konsumsi Pakan \& Minum Hewan Uji

Salah satu tanda gejala diabetes adalah banyak makan karena sering merasa lapar (poliphagia), sehingga konsumsi pakan hewan uji menjadi suatu data tambahan yang dapat diamati berkaitan dengan diabetes (Rismayanthi, 2010).

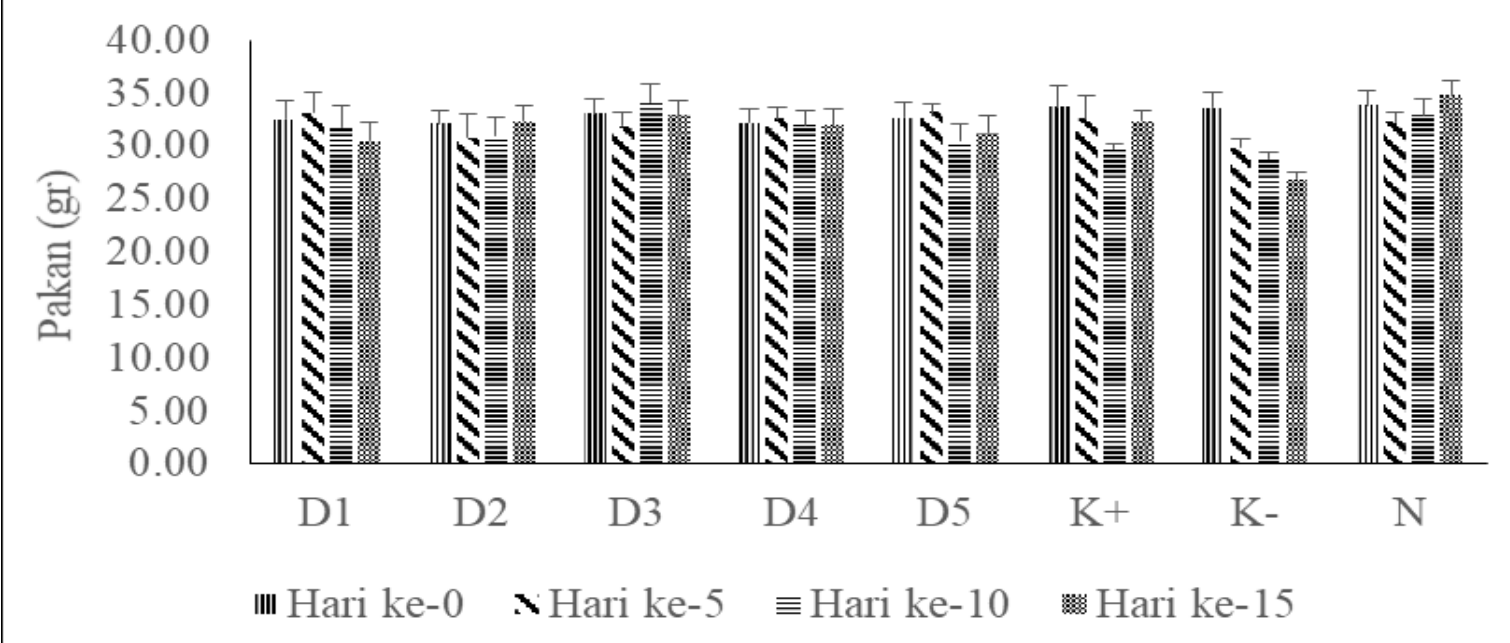

Gambar 2. Grafik Konsumsi Pakan Hewan Uji Selama 15 Hari Pengmatan. D1 (Dosis 12.5 mg/kgBB) ; D2 (Dosis $18.75 \mathrm{mg} / \mathrm{kgBB}$ ) ; D3 (Dosis $25 \mathrm{mg} / \mathrm{kgBB}$ ) ; D4 (Dosis $31.25 \mathrm{mg} / \mathrm{kgBB}$ ) ; D5 (Dosis $37.5 \mathrm{mg} / \mathrm{kgBB}$ ) ; K+ (Kelompok Kontrol Positif) ; K- (Kelompok Kontrol Negatif) ; N (Kelompok Kontrol Normal).

Kelompok $\mathrm{N}$ pada gambar 2 menunjukkan pola konsumsi pakan tikus yang tidak diberikan induksi aloksan. Kelompok N digunakan sebagai pembanding pola konsumsi pakan pada hewan uji. Kelompok $\mathrm{N}$ dibandingkan dengan hewan yang mengalami diabetes baik yang diberikan terapi maupun tanpa diberikan terapi obat.

Pada gambar 2 menunjukkan konsumsi pakan yang menurun dari hari ke-0 sampai hari ke-15 terjadi pada kelompok kontrol negatif (K-), yang mengalami diabetes tanpa diberikan terapi obat maupun ekstrak. Secara literatur, hewan uji yang mengalami diabetes harusnya memiliki konsumsi pakan yang meningkat karena salah satu gejala diabetes adalah nafsu makan yang bertambah [12]. Nafsu makan yang yang bertambah pada kondisi diabetes dapat disebabkan karena glukosa tidak berdifusi dengan mudah melalui pori-pori membran sel. Hal ini menyebabkan gula darah tidak ataupun sedikit yang dimetabolisme dan sumber energi pada tubuh berkurang [10], sehingga tubuh merespon untuk menambah sumber energi dengan meningkatkan nafsu makan. Dalam penelitian ini, penurunan konsumsi pakan yang terjadi pada kelompok Kdapat disebabkan karena tingkat keparahan diabetes oleh efek aloksan yang membuat hewan uji menjadi sakit (Szkudelski, 2001 \& Rohilla, 2012). Kondisi sakit akibat diabetes yang tidak diberikan terapi dapat mengakibatkan terjadinya hilang nafsu makan, mual, serta berat badan yang menurun [13].

Kelompok yang menunjukkan terjadinya penurunan konsumsi pakan juga terjadi pada kelompok D1. Hal ini mungkin terjadi karena dosis esktrak yang tidak cukup kuat untuk membantu memperbaiki kondisi sakit yang dialami hewan uji akibat dari aloksan, sehingga efek aloksan lebih dominan. Sementara konsumsi pakan pada kelompok D2, D3, D4, D5 dan $\mathrm{K}+$ menunjukkan pola konsumsi pakan yang berbeda dengan kelompok K-. Pola konsumsi pakan pada kelompok yang diberi variasi dosis ekstrak dan $\mathrm{K}+$ yang diberi diberi glibenklamid, menununjukkan bahwa hewan uji yang diberi terapi ekstrak maupun obat diabetik oral mampu menjaga kestabilan nafsu makan pada hewan uji. Hal ini dapat disebabkan karena efek ekstrak dan glibenklamid menunjukkan adanya perbaikan jaringan pada sel yang rusak akibat aloksan [11], sehingga kondisi sakit oleh aloksan yang dapat menyebabkan penurunan 
nafsu makan dapat diatasi seiring dengan adanya perbaikan fungsi jaringan [10].

Selain pengamatan konsumsi pakan, pola konsumsi minum yang dihabiskan hewan uji dapat diamati untuk membandingkan perbedaan pola konsumsi minum pada setiap perlakuan. Pola konsumsi minum berkaitan dengan intensitas pengeluaran urin pada hewan uji yang merupakan salah satu tanda gejala diabetes yang disebut poliuria [14]. Pola konsumsi minum hewan uji dapat dilihat pada gambar 3.

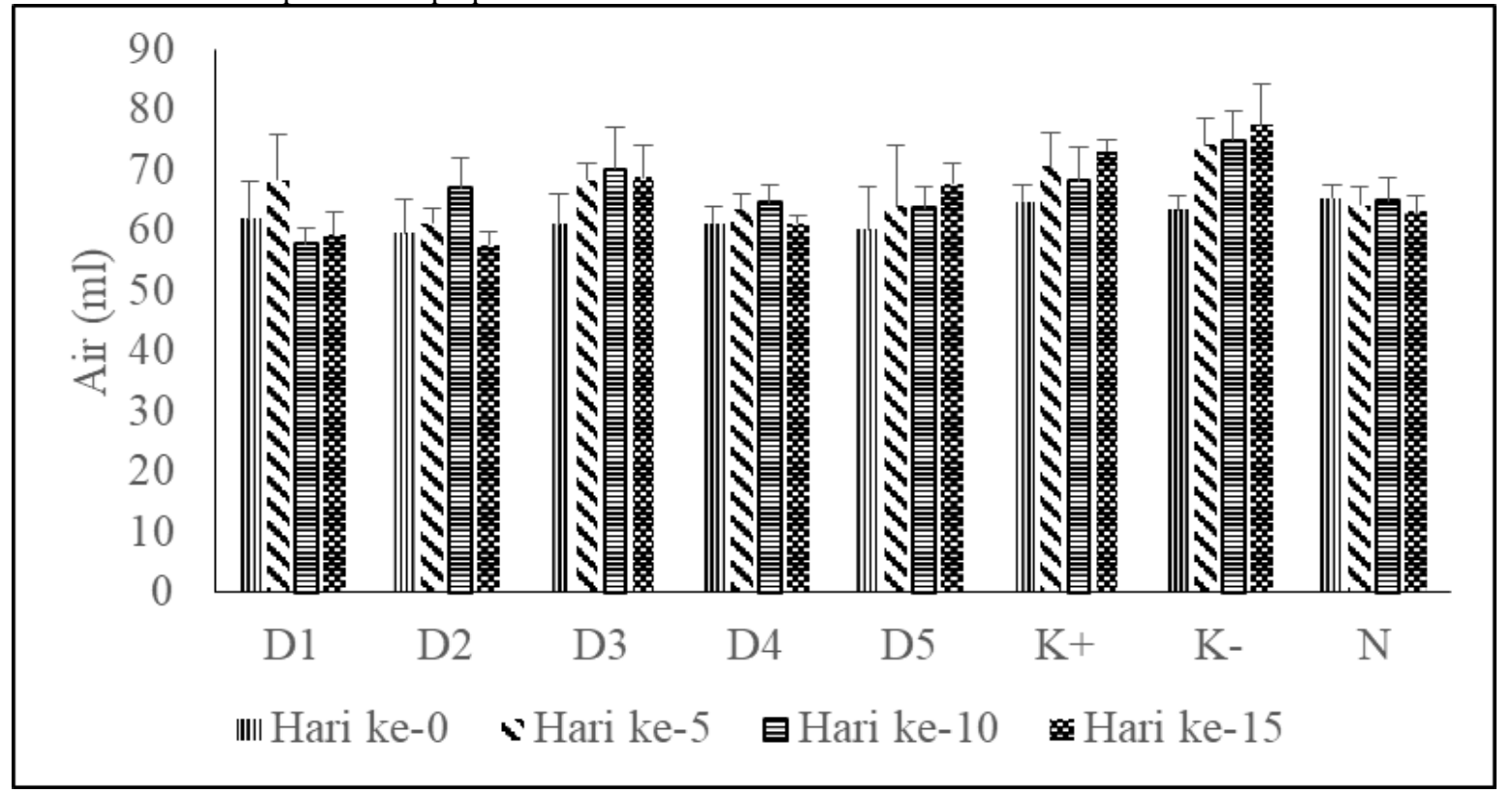

Gambar 3. Grafik Konsumsi Minum Hewan Uji Selama 15 Hari Pengamatan. D1 (Dosis 12.5 mg/kgBB) ; D2 (Dosis $18.75 \mathrm{mg} / \mathrm{kgBB}$ ) ; D3 (Dosis $25 \mathrm{mg} / \mathrm{kgBB}$ ) ; D4 (Dosis $31.25 \mathrm{mg} / \mathrm{kgBB}$ ) ; D5 (Dosis $37.5 \mathrm{mg} / \mathrm{kgBB}$ ) ; K+ (Kelompok Kontrol Positif) ; K- (Kelompok Kontrol Negatif) ; N (Kelompok Kontrol Normal).

Grafik pada gambar 3 menunjukkan adanya pola konsumsi minum pada perlakuan yang mengalami diabetes memiliki konsumsi minum yang lebih tinggi dibandingkan dengan kelompok hewan uji yang tidak daiabetes pada kelmpok N. Hal ini menunjukkan bahwa hewan uji dengan kondisi diabetes pada penelitian ini, memiliki gejala diabetes yang sesuai dengan literatur bahwa kondisi diabetes menimbulkan gejala sering merasa haus [14].

Keadaan sering merasa haus ini dapat diakibatkan karena pada pasien diabetes menimbulkan tingkat diuresis yang tinggi [15], sehingga memerlukan pengganti cairan yang hilang melalui konsumsi air minum. Diuresis yang tinggi pada kondisi diabetes disebabkan karena beban glukosa yang disaring dapat melebihi kapasitas tubulus ginjal untuk menyerap kembali glukosa. Kondisi ini mengakibatkan protein transpor menjadi jenuh sehingga akan teradapat glukosa dalam urin. Glukosa adalah zat terlarut yang menarik air ke dalam urin dengan osmosis. Dengan demikian, hiperglikemia menyebabkan diabetes untuk menghasilkan volume tinggi urin yang mengandung glukosa [15].

2. Gula Darah Puasa Hewan Uji Selama 15 Hari Pengamatan

Hasil penelitian penurunan kadar gula darah tikus diabetes dengan pemberian ekstrak biji buah wali (Brucea javanica L. Merr) pada setiap kelompok dapat dilihat pada gambar gambar 4 dan gambar 5.

Dari gambar 4 dan 5 dapat diamati grafik penurunan gula darah yang signifikan terlihat pada kelompok perlakuan D3 dan K+. Kelompok perlakuan dosis lainnya menunjukkan penurunan gula darah yang tidak stabil hingga pengamatan hari ke 15 . Kelompok $\mathrm{K}$ - tidak menunnjukkan penurunan gula darah yang berarrti dan masih tetap berada dikadar gula darah yang tinggi. Pada kelompok $\mathrm{N}$ terlihat gula darah tetap stabil dan tidak terjadi kenaikan maupun penurunan yang signifikan.

Pada kelompok perlakuan variasi dosis dan kelompok $\mathrm{K}+$ secara umum terlihat adanya penurunan gula darah selama pengamatan. Kelompok perlakuan variasi dosis menunjukan bahwa ekstrak buah wali dapat menurunkan kadar gula darah tikus diabetes. Penurunan kadar gula yang terjadi pada kelompok variasi dosis membuktikan bahwa buah wali memiliki efek menurunkan gula darah. Gula darah yang turun dari efek buah wali dapat terjadi karena buah wali mengandung flavonoid yang memacu proliferasi dan sekresi insulin sebagai mekanisme yang mereduksi hiperglikemia [16]. Buah wali juga dapat memperbaiki jaringan pankreas yaitu meliputi sel endokrin yang mulai melakukan regenerasi menuju bentuk normal [11], sehingga dapat memulihkan sel beta 
pankreas untuk sekresi insulin dan gula darah dapat dimetabolisme.

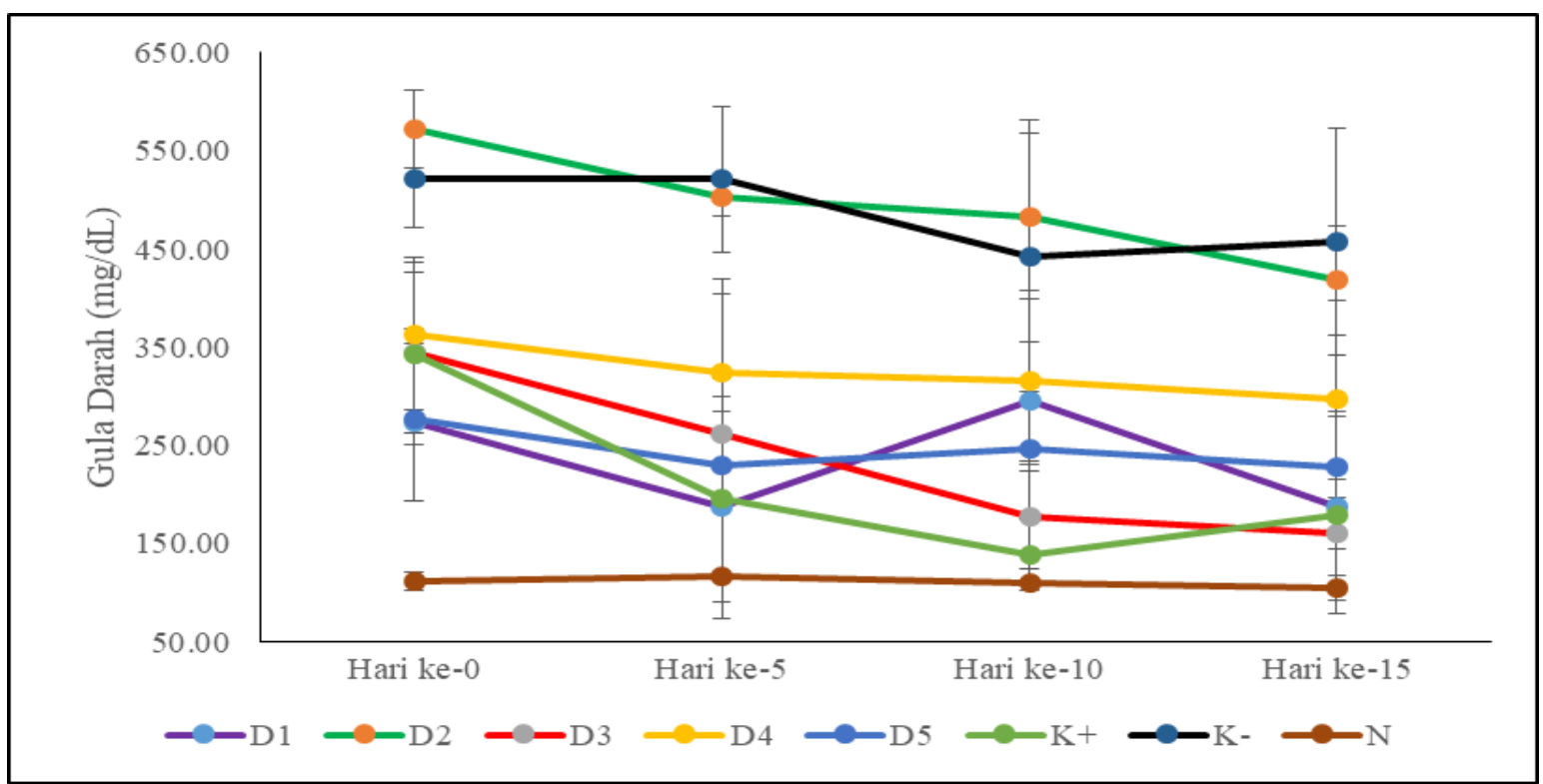

Gambar 4. Grafik Gula Darah Puasa Hewan Uji Selama 15 Hari Pengamatan. D1 (Dosis $12.5 \mathrm{mg} / \mathrm{kgBB}$ ) ; D2 (Dosis $18.75 \mathrm{mg} / \mathrm{kgBB}$ ) ; D3 (Dosis $25 \mathrm{mg} / \mathrm{kgBB}$ ) ; D4 (Dosis $31.25 \mathrm{mg} / \mathrm{kgBB}$ ) ; D5 (Dosis $37.5 \mathrm{mg} / \mathrm{kgBB}$ ) ; $\mathrm{K}+$ (Kelompok Kontrol Positif) ; K- (Kelompok Kontrol Negatif) ; N (Kelompok Kontrol Normal).

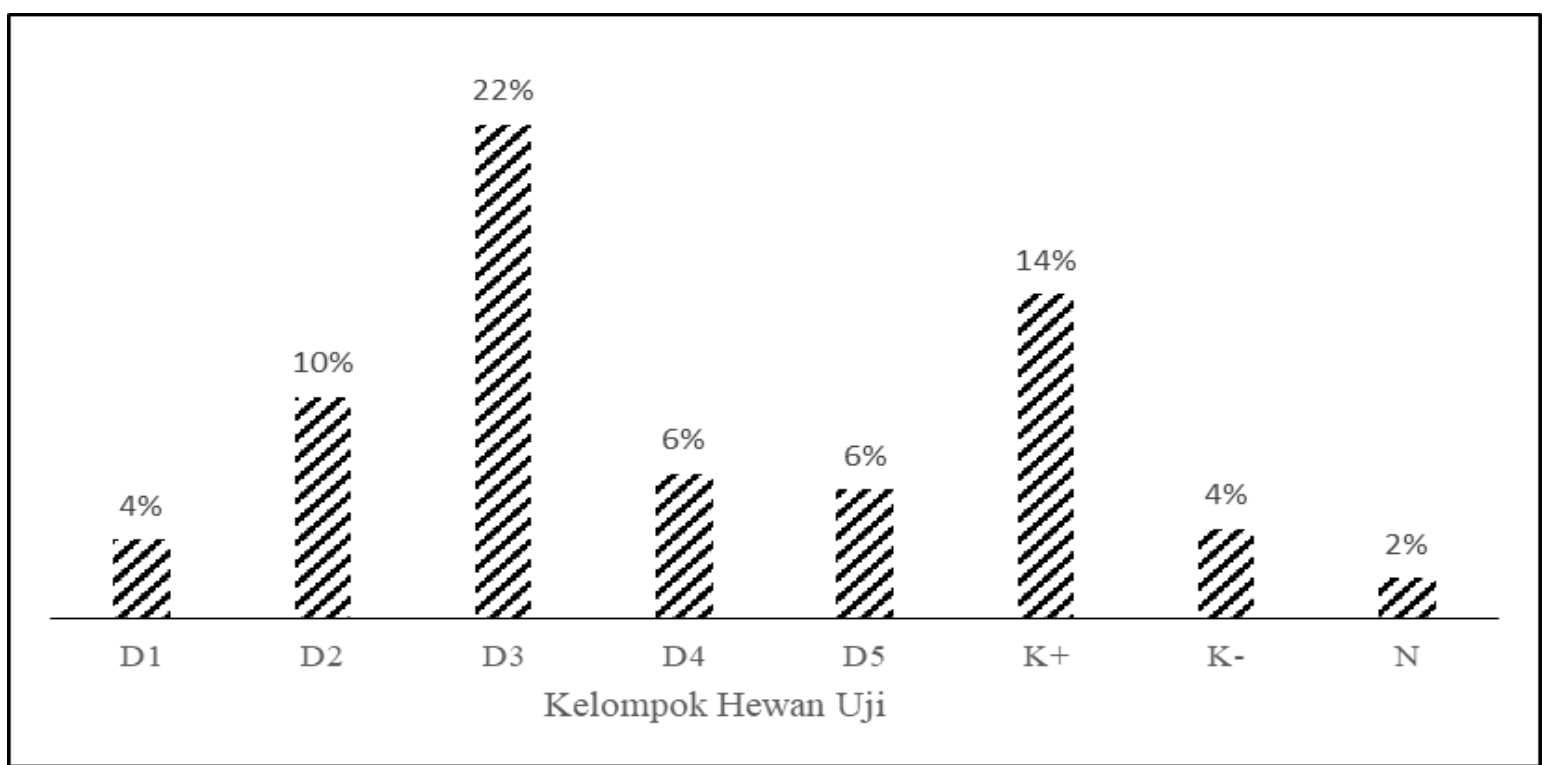

Gambar 5. Grafik Persentase Penurunan Gula Darah Puasa Hewan Uji Selama 15 Hari Pengamatan. D1 (Dosis $12.5 \mathrm{mg} / \mathrm{kgBB}$ ) ; D2 (Dosis $18.75 \mathrm{mg} / \mathrm{kgBB}$ ) ; D3 (Dosis $25 \mathrm{mg} / \mathrm{kgBB}$ ) ; D4 (Dosis $31.25 \mathrm{mg} / \mathrm{kgBB}$ ) ; D5 (Dosis $37.5 \mathrm{mg} / \mathrm{kgBB})$; K+ (Kelompok Kontrol Positif) ; K- (Kelompok Kontrol Negatif) ; N (Kelompok Kontrol Normal).

Disamping kelompok perlakuan variasi dosis, penurunan gula darah terjadi pada kelompok $\mathrm{K}+$. Kelompok $\mathrm{K}+$ merupakan kelompok dengan pemberian glibenklamid 0.5 $\mathrm{mg} / \mathrm{kgBB}$. Penurunan gula darah akibat pemberian glibenklamid sudah banyak diketahui, karena obat ini bekerja merangsang sekresi insulin di kelenjar pankreas [17]. Rangsangan dengan menutup kanal potassium pada membran sel $\beta$ yang akan menimbulkan depolarisasi membran dan keadaan ini akan membuka kanal Ca. Terbukannya kanal
Ca makan ion Ca akan masuk sel $\beta$, merangsang granula yang berisi insulin dengan jumlah ekuivalen dengan peptide-C [17].

Kelompok $\mathrm{N}$ pada gambar 4 memiliki kadar gula darah msih pada rentan normal $(<135$ $\mathrm{mg} / \mathrm{dL}$ ), hal ini sesuai dengan fungsinya sebagai pembanding gula darah hewan uji yang mengalami diabetes dan tidak mengalami diabetes [6]. Dari grafik pada gambar 4 dapat diketahui hewan uji yang tidak dalam kondisi sakit maupun diabetes memiliki grafik gula 
darah yang stabil dan dibawah kategori diabetes yaitu $<135 \mathrm{mg} / \mathrm{dL}$.

Kelompok hewan uji lain yang dijadikan sebagai kontrol adalah kelompok K-. Kelompok $\mathrm{K}$ - ini berfungsi sebagai pembanding gula darah hewan uji diabetes yang tidak diberikan terapi obat. Gula darah pada kelompok K- tidak mengalami perubahan berarti dan tetap masuk dalam kategori diabetes. Pada kelompok Kmenunjukkan bahwa hewan uji yang tidak mendapatkan terapi mengakibatkan gula darah tetap dalam kadar yang tinggi akibat dari efek aloksan yang diberikan [18]. Adapun penurunan darah pada kelompok K- jika dilihat pada gambar 4 terjadi pada hari ke-10. Hal tersebut dapat terjadi karena hewan uji memiliki antioksidan endogen yang berperan sebagai kemampuan alami hewan uji untuk mengobati efek aloksan [10]. Kemampuan alami hewan uji untuk mengobati diri sendiri belum cukup kuat untuk mengimbangi efek aloksan, sehingga didapat grafik yang tidak stabil dan gula darah masih dalam rentang yang tinggi.

Ekstrak biji buah wali pada penelitian ini menunjukkan efek penurunan gula darah puasa apabila diberikan pada hewan uji tikus diabetes yang diinduksi aloksan. Pada Gambar 4.5 menunjukkan bahwa persentase penurunan gula darah yang paling besar terjadi pada kelompok D3. Hal ini menunjukkan bahwa dosis ekstrak 25 $\mathrm{mg} / \mathrm{kgBB}$ memberikan efek penurunan yang paling baik diantara variasi dosis ekstrak lainnya.

\section{KESIMPULAN}

Variasi dosis esktrak yang diturunkan dari dosis yang biasa diminum masyarakat Sesaot dapat memberikan efek terhadap penurunan gula darah pada hewan uji diabetes yang diinduksi aloksan. Variasi dosis yang memiliki efek penurunan terbesar terdapat pada kelompok D3 dengan dosis ekstrak $25 \mathrm{mg} / \mathrm{kgBB}$. Penurunan gula darah pada dosis tersebut disertai dengan perbaikan kondisi hewan uji yang diamati dari data berat badan, konsumsi pakan dan minum.

\section{DAFTAR PUSTAKA}

[1] Utami, Prapti \& TIM. 2003. Tanaman Obat Untuk Mengatasi Diabetes, Sehat dengan Ramuan Tradisional. Jakarta : Agro Media, p. $1-2$

[2] World Health Organization. 2016. Global Report On Diabetes. Geneva: WHO Library Cataloguing-in-Publication Data.

[3] Shaw, J.E., R.A. Sicree., P.Z. Zimmet., 2009. Global estimate of the prevalence of diabetes for 2010 and 2030. Baker IDI Heart and Diabetes Institute. p. 4-14.

[4] Dalimartha, S. Atlas Tumbuhan Obat Indonesia. Jilid 2, Jakarta: Perpustakaan Nasional RI, p. 28-32.

[5] Szkudelski T., Kandulska K., \& Okulicz M. 1998. Alloxan in vivo does not only exert deleterious effects on pancreatic B cells. Department of Animal Physiology and Biochemistry., Physiol. Res. 47: 343-346.

[6] Gad, S. C. 2007. Animal Models in Toxicology. $2^{\text {nd }}$ Ed. United States of America: CRC Press.

[7] Ary, D., Jacob, L.C. \& Razavieh, A. 1985. Pengantar Penelitian Dalam Pendidikan. Edisi 3. Diterjemahkan oleh Arief Furchan. Y ogyakarta: Pustaka Pelajar.

[8] Saifudin, A., 2014. Senyawa Alam Metabolit Sekunder: Teori, Konsep, dan Teknik Pemurnian. Yogyakarta: Deepublish, p. 47-113

[9] Craig, L. C., Gregory, J. D., \& Hausman W., 1950. Versatile laboratory concentration device. Analytical Chemistry. Journal. p. 1462-1462.

[10] Dyahnugra, A. A. \& Simon B. W., 2015. Ekstrak Bubuk Kulit Manggis Menurunkan Kadar Glukosa Darah Tikus .Jurnal Pangan dan Agroindustri, Vol. 3 No 1 p. 113-123.

[11]Djuanda, A. R., Anna P., Waras, N. 2011. Potensi Fraksi Air Buah Makasar (Brucea javanica L. Merr) Terhadap Gambaran Histologi Pankreas Tikus yang Diinduksi Aloksan. UT - Biochemistry. Diakses dari https://repository.ipb.ac.id/bitstream/handle 1123456789/48220/BAB\%20V\%20Simpula n $\% 20 \mathrm{G} 11$ adj.pdf?sequence=8\&isAllowed =y pada tanggal 10 Juli 2018.

[12] Chaudhury, A., Chitharanjan, D., Vijaya, S.R.D., Shashank, K., Aditya, C., Rahul, R., Asween M., Nawal, S. S., Maria, T.M., Kevin, K., Appalanaidu, S., Alexandria, B., Naveen, P., Chaitanya, K.M., Govinda, P.L., \& Wasigue, M., 2017. Clinical Review of Antidiabetic Drugs: Implications for Type 2 Diabetes Mellitus Management. Frontiers in Endocrinology. Vol.8, No.6, p. 4.

[13] Tjokroprawiro, A., Prof. DR. dr. SpPDKEMD. 2006. Hidup Sehat dan Bahagia Bersama Diabetes Mellitus. Jakarta : PT. Gramedia Pustaka Utama.

[14] Rismayanti, C., 2010. Terapi Insulin sebagai alternative pengobatan bagi penerita diabetes. Mediakora, Vol. VI, No. 2, p. 29-36

[15]Wang, S., Grace M \& Raimund R., 2008. Osmotic polyuria: an overlooked mechanism in diabetic nephropathy. Nephrol Dial Transplant., Vol. 23: p. 21672172.

[16] Sri B, Rukkumani R, Viswanathan P, Menon P.V. 2004. Ferulic acid alleviates lipid peroxidation in diabetic rats. Phytother. Res. 18: 310-314. 
[17] Syarif, Amir., Ari E., Arini S., Armen M., Azalia A., Bahroelim B., Frans D.S., Hedi R.D., Hendra U., Iwan D., Metta S.S.W., Nafrialdi., Petrus F.W., Purwantyastuti A., Rianto S., Sunaryo., Srimarti W., Suharti K.S., Sulistia G.G., Vincent H.S.G., Wawaimuli A., Yanti M., Yati H.I., Zunilda D.S., Melva L., \& Elysabeth., 2009. Farmakologi dan Terapi. Edisi 2. Jakarta: Balai Penerbit FKUI. p. 490495.

[18] Radenkovi'c M., Stojanovi'c, M. \& Prostran, M., 2015. Experimental diabetes induced by alloxan and streptozotocin: The current state of the art. Journal of Pharmacological and Toxicological Methods. p. 8-23. 